\title{
China as a future normative power: A Chinese Cultural perspective
}

\author{
Leei Wong \\ Lecturer, HASS, Sheridan College, Perth, Australia \\ (Iwong@sheridan.edu.au) \\ Received 31 January 2018
}

This journal is licensed under a Creative Commons Attribution-NonCommercial 4.0 International License (CC-BY-NC). Articles can be read and shared for noncommercial purposes under the following conditions:

- BY: Attribution must be given to the original source (Attribution)

- NC: Works may not be used for commercial purposes (Noncommercial)

This license lets others remix, tweak, and build upon your work non-commercially, and although their new works must also acknowledge you and be non-commercial, they don't have to license their derivative works on the same terms. License Deed Link: http://creativecommons.org/licenses/by-nc/4.0/

Legal Code Link: http://creativecommons.org/licenses/by-nc/4.0/legalcode

$A B C$ Research Alert uses the CC BY-NC to protect the author's work from misuse.

\section{Abstract}

This paper discusses Western and Chinese views on China's growth to highlight the differences in perspectives regarding the outlook of China's future. An overview of the features of a normative power and an examination of the challenges China faces when she interacts with its neighbors will elicit traces of its potential normative style in the region. We will then conclude that China is in a dilemma in exhibiting its normative power, and it seeks to reconcile the situation through managing sovereignty issues with its neighbors in a consistent way and proposing initiatives such as the AIIB and the 21st Century Maritime Silkroad to help portray itself as a responsible and accepted normative strength.

\section{Keywords}

China; Normative Power; Chinese Culture

\section{INTRODUCTION}

The rapid transformation of China's economic potential is indeed a global limelight in the 21 st century, and with the emergence of China as an economic great power and gradual growth of military strength in the Asia-Pacific, the inquiry of China as a normative power is crucial. However, studies on normative power is scarce and only of 'recent provenance' (Kavalski,2013) and "hardly been broached in the analysis of Asian international affairs" as compared to studies of soft power that forms most of the increasing interest. Normative power, contrary to military or economic power is defined by how the' relations of asymmetry are managed' and about building a more secure and prosperous world (Kavalski, 2014). 


\section{Western vs Chinese views on China's growth}

As China rises to its present achievements, China's seemingly ambitious desire to be the Big Brother dominating the world is certainly causing uneasiness amongst its neighbors and the US. However, a review of recent literature puts the West at ease that it is highly improbable that China will replace America (Nolan 2013, Fenby 2014, Smith 2015), like what America did to the Great Britain in history.

Most Western scholars and the general public also reject Jacques' (2012) differing opinion about China that it will take over the western world. However, in a pew survey, more than $58 \%$ of the people in China thinks that China will replace U.S. as Superpower (diagram 1), the highest percentage among the 39 countries. Zhang Yu, professor from the School of Economics at Renmin University of China commented about the faulty Western economics mainstream view regarding China's economy's "collapse", as being "dogmatic". He urges for "the general principals" to be resolved when viewing the economy of China and prides China's unique model of the combination of socialism and market economy as the "first time in human history".

Sanguinity and confidence towards China's future prospects is eminent not only domestically but also amongst overseas Chinese. Singapore's Lee Kuan Yew comments that China's rise is not from nothing but is "fuxing" (revival, restoration) and he predicts that "in 2022, China may have built its own space station and assembled the military might to confront US strategic resolve in Asia".

Also, Taiwan's scholar Shih Chi-ping has likened China's rise to the unification of China under the Qin Dynasty in 221 BC whereby the present China is employing the same 'zonghengbaihe' tactics, just as Qin was trying to eliminate the other States and establish hegemony.

The current state of China is described in popular beliefs as between the stages of huoyuezai yuan (' as if it were leaping up, but still in the deep; taking a trial) and "fei long zai tian ('The dragon is on the wing in the sky; the subject is high and ruling) in Yijing ("Classic of Changes"/ "Book of Changes") , having gone through the stages of "qian long wuyong'('The dragon lies hid - it is not the time for active doing')--- jian long zai tian('The dragon shows himself and is in the field'--the time (requires him still) to be unemployed.); zongriqianqian ('All the day active and vigilant:'--(he now) does his (proper) business.); and the last stage of 'kang long you hui'"( 'The dragon exceeds the proper limit, and there will be occasion for repentance:'--when things have been carried to extremity, calamity ensues) is referred to the future. In other word, the 'dragon' is emerging and trying to establish it presence at this moment.

The overall optimism towards China's future is a great contrast to the Western scholars' view. For China, the overall laymen and the leaders believe that the country is progressing and overseas Chinese leaders trust in the future China to establish itself in the global stage as an important player. However, does this optimism indicate undivided support it will render China? Does China's emerging presence indicate it can become a normative power? 


\section{Normative power East and West}

Ian Manners (2002) provides a basis of the concepts of Normative power --- to look at 'EU in global politics', 'conceptualizing the EU as a global actor'. Following Manners (2002), Reichenbach (2008) extracted five 'core' norms, namely, Peace; Liberty; Democracy; Rule of law and Human rights in a European normative power. Furthermore, there are four 'minor' norms: Social solidarity; Anti-discrimination; Sustainable development and Good governance. China is seen as facing the challenges from the Western-dominated international society, and China does not seem to want to conform to the "new standard of civilization "(Wang, p 241), and has its own distinctive features in establishing itself as a normative power.

Kavalski $(2013,255)$ states that China's normative power can be elicited from its 1) peaceful rise to international status 2) non-interference in the domestic affairs of states and 3) preservation of Chinese national values. The present China normative power is "informed by its 'philosophical oeuvre', namely Confucianism, Daoism and works of pre-Qin thinkers (Kavalski,2014). He also explains China's normative power by expanding on Brantley Womack's proposal to as 'logic of relationships' (p.314) as opposed to the Western version of 'logic of appropriateness' (p.314) ; and quotes Deng Xiao Ping's “do as I do"( 2009,1$)$ as opposed to the European 'do as I say, not as I do' $(2009,11)$ form of normativity. Pu (2012) also claims that "non-western normative orders are just as legitimate as western ones".

China has always been stressing on a "peaceful rise" and $\mathrm{Xi}$ Jinping, in his speech in Germany 2014 stressed that 'China's pursuit of the path of peaceful development is to inherit and carry forward the Chinese cultural tradition of the love of peace'. He also stressed that China opposes hegemony and power politics; never intervenes in other countries' internal affairs; never seeks hegemony or expansionism. China repeatedly expresses that they have 'stated so in policy, laid out such system, and have been acting accordingly in practice' but also highlights that they will 'unswervingly safeguard its sovereignty, security and interests for development'.

Wang (2012) explains that one of the difficulties for today's China which brings complex relations with EU is that the Socialist state still feels the cultural gap with EU. Edward Said's Orientalism suggests the difference in perceptions with regards to Western and East views. Can China's new form of normative power be convincing to the European world? Before looking at China in the international stage, we will look at whether the binding elements of 'Asian values' in Southeast Asia can serve as a lubricant for China to be recognized as a legitimate normative power in the region.

\section{A Normative leader --- recognition of power status in Southeast Asia}

Kavalski $(2013,248)$ distinguishes the difference between Mannes and Jackson's theories in that 'the reference to normative power suggests an ability to frame what is acceptable and what is unacceptable behavior'; and stresses on Jackson's view on 'legitimacy needs to be earned'. Baviera (2011) suggests that a rising power China's best chance of finding legitimacy and acceptance is through recognition of its great power status by its Southeast Asian neighbors". 
When answering the question on China's policy towards the neighboring countries, Xi Jinping pointed out at the Nuclear Security Summit last year, that, a nearby neighbor is better(more helpful) than a far-off relative. China seeks to 'develop friendship and partnership with their neighbors and adheres to the ideas of "affinity, sincerity, mutual benefit, and inclusiveness".

However, Dibb and Lee (2014) observe that China is "a lonely power when it comes to acquiring real influence in Asia"; and that many Southeast Asian countries "have taken steps to align themselves closer to the United States". China stresses on an overall sound relationship with its neighbors. Concerning the major issues and principles of China's sovereignty and territorial integrity, China claims that they will not stir up troubles, but will never be afraid of troubles. The "firm persistence to safeguard the legitimate rights of China" is the main cause of the Southeast Asian's distress.

The South China Sea dispute shows that China is experiencing a dilemma: On one hand, it strives to 'rise harmoniously', on the other hand, its sense of presence in the region is causing adaptability issues with its neighbors. They are not accustomed to China's growing presence in the region to "fen yi ben geng" (have a finger in the pie). China has to take into considerations the worries of small nations when a giant like them is having activities around them. The distrust due to historical reasons; the present authoritarian state regime of China and the ambiguity of the San Francisco treaty aggravates the situation.

\section{Adapting to China's presence -- ' junzi he erbu tong'}

China Foreign Minister Yang Jiechi has remarked that "China is a big country and other countries are small countries, and that's just a fact"(Baviera,2011) at the17th ASEAN Regional Forum and its attitude is interpreted as imperious. As Mozi said: The will of Heaven abominates the large states which attack small states. The large house which molests small houses, the strong who plunder the weak, the clever who deceive the stupid, and the honored who disdain the humble - these are what the will of Heaven abominates. (Feng, 1983,97). Is the big power China using its strength and size to dominate and promote its interests?

The Foreign minister may have lost his composure, when US Secretary of State then, expressed support for freedom of navigation in the South China Sea, backing the Southeast Asian claimants in the region. Hillary Clinton's remark is interpreted as "an attack on China" and henceforth the abrupt expression.

There are other examples when China exhibits its exasperations. The most recent one being one of the eight warnings, "You go!" issued by the Chinese navy officer to the US' most advanced surveillance spy plane, the P8-A Poseidon.

Deng Xiaoping, who once advised that China should "bide its time and conceal its capabilities until it is ready to act." Is this the time where China is beginning to 'act'? China has been taking a lower-profile composure with regards to the South China Sea issue. As China begins to assert its sovereignty rights, it causes uneasiness and creates fear. China is awaiting recognition of its power status even in the Southeast Asian region and only through meaningful dialogues and negotiations can China mitigate the problems. 
However, we can see China's consistency in managing its relationships with its counterparts. The emphasis on respect for the others echoes the Confucian teaching of "harmony with difference"---junzi he erbu tongin Analects 13.23.It literally means, "The gentleman is harmonious and is open-minded; the non-gentleman, can gather together easily but they do not stay together for long." In other words, traditional Chinese philosophy advocates that interactions based on respect for (not in total agreement) those different from us will allow meaningful engagements to occur (Kavalski,2013).

\section{Who is breaking the International Law?}

U.S. Secretary of State John Kerry has raised concerns with Beijing's top officials this month, over its large-scale land reclamation, which undermines peace and stability in the South China Sea. This is not the first time US is warning China of its actions. In July 2010, the US Secretary of State then, Hillary Clinton called for China to resolve the territorial dispute, but was greeted by China's demand of the US to stay out of the matter. China has signed up to the United Nations Convention on the Law of the Sea (UNCLOS)in 2002 with ASEAN, which sets the rules for territorial claims, but the reclamation works deemed her "underestimating the International Law".

On China's side, she is perplexed by US's continuous 'interference' of the issue. This coincides with what Wang(2012) description of EU's normative power's “contradictions' and 'limitations' because of its lack of "Tao" realm, from the Chinese cultural perspective. According to him, traditional Chinese culture has "four kinds of normatively informed powers--Li;Tao;Fa; and Shu". The eagerness to "intervene in the internal affairs of others" shows the lack of respect of the "principal of "Tao".

In 2013 Foreign Minister Wang Yi blamed the US "interferences" with regards to the negotiations of the Code of Conduct with ASEAN. In a recent meeting with U.S. Secretary of State John Kerry, China's Foreign Minister Wang Yi reaffirms that "China's determination to safeguard its sovereignty and territorial integrity is as hard as a rock". It is evident that both sides need to come to common grounds on the matter, which has been unresolved for many years. The China Defense Minister Liang Guangliealso commented that "Only Asians should lead the process to resolve regional issues," and evidently wants U.S. to back off from any discussions of the code of conduct with its neighbors.

Yujuico E., a research fellow at LSE IDEAS Southeast Asia International Affairs Programme comments that it is highly questionable that America brings up the "international law" as justification as it has not even ratified the convention. Therefore, claims for American to be involved is not justifiable, as the US does not even abide by the international law in this case regarding maritime jurisdiction.

And, the US applies a double standard with regards to reclamation works in the South China Sea. Chinese Foreign Ministry spokesman Hong Lei expressed last month that Vietnam, Philippines and other countries have been carrying out reclamations on the islands. On Thitu Island, the Philippines is building an airport and expanding a wharf; and others are building "so-called tourism facilities". According to him, Vietnam is also military facilities on more than 20 islands and shoals, including Prince Consort Bank and Orleana Shoal. 


\section{Problem of Peace Treaty and A Divided ASEAN}

In the San Francisco Peace Treaty signed in 1951, Article II states that, " Japan renounces all right, title and claim to the Spratly Islands and to the Paracel Islands". But the crux of the problem is that it did not indicate the "return to China". Therefore, according to the principle of UtiPossidetis and occupation, the Republic of China has the right of sovereignty to both islands since that critical date (Chen,2014).

Not every ASEAN member state is involved in the territorial disputes. The Philippines is the only country amongst the claimants to lodge the dispute to a UN tribunal and recently, at the 26th ASEAN summit, President Benigno Aquino III and Foreign Affairs Secretary Albert del Rosario issued separate statements calling for ASEAN consensus on China's expansion in South China Sea. However, Malaysian leader expressed that ASEAN will be "non-confrontational" as opposed to the Philippines' harder line against Chinese territorial claims.

China has been actively seeking engagement with ASEAN countries, from supporting the ASEAN Plus Three (APT) forum and Asia Regional Forum (ARF) to engaging ASEAN with mutual economic benefits and by extending its soft power by financing or building infrastructure projects . And, considering the number of diaspora in the ASEAN countries, populations of overseas or ethnic Chinese in ASEAN may play a part in favoring a positive relationship with China. In any way, ASEAN countries each has its own agenda and lining up with China could be a pragmatic choice.

\section{Size does matter}

China has its own set of serious environmental problems, but when it comes to the international stage, she could show more responsibility towards the shared environment issues with neighboring countries. On April 2015, the Philippine Department of Foreign Affairs (DFA) states that China is causing "irreversible and widespread damage to the biodiversity and ecological balance of the South China Sea". As reclamation works continue in the South China Sea, it threatens the ecological system of the sea, which is like the Mediterranean, shallow and mostly enclosed. Reclamation works destroys reefs and encourages an ecological catastrophe.

Besides reclamation works, Chinese fishermen are also irresponsibly poaching endangered species "tolerating harmful practices and harvesting of endangered species" protected under the $\mathrm{CBD}$ (Convention on Biological Diversity) and the CITES (Convention on International Trade in Endangered Species of Wild Fauna and Flora).As Merced (2015) reports recently that it is vital for a huge nation like China to realize that the "sheer scale of their actions can have wider impact on the environment". China must 'demonstrate their commitment to marine environment protection' to earn the respect of the international partners. China has to exhibit responsible behavior when it maneuvers due to its sheer size and it has to portray "acceptable behavior" through its negotiations with the nations.

\section{Rallying Nationalist sentiments in the East China Sea?}

Jessica Chen Weiss from Yale University states that in authoritarian diplomacy, "Nationalist protests enable autocrats to claim credibly that they cannot maintain the status quo or meet 
foreign demands". In other words, the anti-Japanese protests that took place in 2012 regarding the Senkaku Islands row shows that China is exploiting the dispute to justify its actions. However, China maintains its commitment to "road of peaceful development," and that they "absolutely" will not sacrifice their "core national interests". This coincides again with Kavalski's $(2013,255)$ views as mentioned earlier that China's normative power can be elicited from its peaceful rise; non-interference in the domestic affairs of states and the preservation of Chinese national values.

The Japanese government has seized the opportunity and allocated $\$ 42$ billion defense budget and reinterpreted Article 9 in the Constitution, allowing "collective self-defense" whereby Japanese self-defense forces can "now be deployed to assist allies under attack". With regards to this, veteran Chinese diplomat Chen Jia accuses the US for deliberately using Japan to contain China and encouraging the revival of Japanese militarism.

The Vice Foreign Minister Fu Ying's reply to a question from a Japanese reporter about Xi's foreign policy is as "aggressive" by retaliating that China has to be "tougher" against Japan's unilateral "nationalisation" of the Senkaku/Diaoyu islets. It indicates that China seeks peaceful engagements (yi he weiguai) but when provoked, they believe in an eye to an eye (yi qi renzhidao, huanzhi qi renzhishen” as what the Song dynasty neo-ConfucianistZhu Xi(朱喜) advocates in "The Doctrine of the Mean" (zhongyong).

\section{Contested sovereignty (Taiwan)}

In 2000, Soong Chu-yu, proposed a "cross-straits union modelled on the European Union" new model for China-Taiwan relations (Hoare and Susan Pares,2005,304)---the EU Normative order. However, the proposal was not taken into consideration and in 2005, China implemented the controversial Anti-Secession Law, and to date, Beijing has not given up the thought of unification through its expanding military force.

Contested sovereignty, and the outcome of the controversial Cross-Strait Service Trade Agreement (CSSTA), prohibits China from being recognized by Taiwan as a legitimate normative power. Manners (2002) "the concept of normative power involves 'normative justification rather than the use of material incentives or physical force'.

$\mathrm{Xi}$ has shown impatience in the issue and in 2013, when he called for a "final resolution" of political disputes between China and Taiwan, and commented that the issues "cannot be passed on from generation to generation". China's exasperations is again manifested due to the resisting forces regarding the cross -straits tension.

\section{China's strategies}

The contested sovereignty is a hindrance for China to become a recognized normative power. Therefore, China is trying to exhibit its normative strength through 'Constructive engagement' (Manners, 2013) by setting up the Asian Infrastructure Investment Bank (AIIB), and to date it has 57 Prospective Founding Members (PFM). The Obama administration's efforts to withhold countries from signing on the AIIB has been futile and the decision by its allies such as the UK, France, Germany, and Italy, signals that the US is gradually being isolated. Even, Taiwan submitted its letter of intent to join the AIIB with the impression that Taipei has conceded to the One China framework. 
The anticipated economic benefits are the pushing factor for the PFM's joining decisions as contrast to what Manners' $(2013,252)$ proposed 'normative justification' (absence of material or physical force) as part of the characteristics of a normative power. And the "maritime silk road" concept was proposed specifically in relation to ASEAN---the ASEAN-China Maritime Cooperation. China is setting its own norms and the move will serve as an effective diversion of the row at the South China Sea, which we have seen previously that mainly is still a major concern for the Philippines and Vietnam. China is creating economic incentives and shifting the focus of the region to woo the ASEAN states.

\section{China's presence in contrast to US presence in the Southeast Asian region}

Another challenge for China is that, China's neighbors seem to choose to align themselves with US in the same way when the Northeast Asia countries aligned themselves with America during the Cold War. This is mainly due to the US naval long-time presence in the region since the Cold War. Another reason could be attributed to the geographical location of China as compared to the US. If military force is to be used, the general perception is that China will be more lethal as compared to the US due to historical reasons. Over the years, US has earned the trust between the countries in the region and in fact, the U.S. military presence in the region is appreciated. The U.S. military commander for the Pacific, Keating claims that not only naval capacities, "massive air and sea capabilities are invaluable in times of natural disaster or other emergencies" in that they create security in the region so that Asian governments can focus on "economic and social transformations".

\section{CONCLUSION}

As China continues to play a major role in the international arena, we can expect to see more alternative traits and measures that emerge with China's rise. China could be viewed as an emerging normative power, and trying to set the 'norms' and $\mathrm{Xi}$ even calls for the "Asia-Pacific Dream" with China as the norm-setter.

Regarding China's neighbors, we can anticipate in the future that they will neither join forces with America nor balance against China, or bandwagon with China. They will remain neutral in their stance just as what ASEAN countries are doing now-- not joining the Philippines in confronting China. Whether America diminishes in the backdrop is yet another question.

As mentioned in the beginning, Kavalski $(2013,255)$ describes evidences of China's normative power can be seen from its peaceful rise (he ping jue qi),non-interference in other states' matters nature and preserving China's national values. China's consistency in managing its relationships with its counterparts and the emphasis on the Confucian's notion of respect for the others is also evidence of how China portrays its normative power.

After World War II, beginning with the French -German reconciliation, the Western world learned to deal with the battle between the religious and secular authority and also learned to overcome hostilities between nation-states. Europe wanted to globally promote their ideas and system designs to impact the world and Normative power Europe took five decades to establish a set of normative principles.

China's rise symbolizes a different set of values, as contrast to the Western norms which emphasizes democracy, human rights, environmental protection and ecological civilization 
values.China's emphasis is to promote the Confucian worldview "tian ren he yi"("Harmony of man and universe") as the ultimate state.China stresses a peaceful global development that caters to the needs of the vast number of developing countries and developed countries especially after the global recession. Neither has China harbour global hegemony intentions as cited in the ancient Laozi's Tao Te Jing chapter eight," shangshanruoshui, shuishan li wan wuerbuzheng" -- The best virtue is like water's. Water benefits everything in the world but does not contend for power.With this aspect, China's rise has obviously a normative role to playin transmitting norms.

\section{References}

Aileen S. P. BAVIERA (2011) China: Less Charm, More Offensive "China is a Big Country, Other

Countries are Small Countries": Analyzing the Facts of Power Asymmetry. http://www.isis.org.my/files/25APR/paper_ps2_aileen_baviera.pdf.University of the Philippines.

Chinese Text Project. http://ctext.org/(retrieved on 21 May 2015)

Chris Buckley. In Lee Kuan Yew, China Saw a Leader to Emulate MARCH 23, 2015

http://sinosphere.blogs.nytimes.com/2015/03/23/in-lee-kuan-yew-china-saw-a-leader-to-emulate/?smid=tw-shar e (retrieved on 2 May 2015)

David Brunnstrom and Michael Martina." U.S., China clash over disputed South China Sea".

http://www.reuters.com/article/2015/05/16/us-usa-kerry-china-southchinasea-idUSKBN0O104Q20150516. (accessed 16 May 2015)

Declaration On the Conduct of Parties in the South China Sea.

http://www.asean.org/asean/external-relations/china/item/declaration-on-the-conduct-of-parties-in-the-south-chi na-sea.(retrieved on 20 May 2015)

Emmanuel Yujuico.The real story behind the South China Sea disputeInternational Affairs,

Diplomacy and Strategy @ LSE.http://www.lse.ac.uk/IDEAS/pdf/SEAPpdf/SA_southchinaseadispute.pdf

Foreign Minister Wang Yi On Process of "Code of Conduct in the South China Sea"

http://www.fmprc.gov.cn/mfa_eng/wjb_663304/wjbz_663308/activities_663312/t1064869.shtml. 2013/08/05(retrieved on 20 May 2015)

Hurng Yu Chen Territorial Disputes in the South China Sea under the San Francisco Peace Treaty.

The real story behind the South China Sea dispute.Issues \& Studies@ 50, no. 3 (September 2014): 169-196.http://tkuir.lib.tku.edu.tw:8080/dspace/bitstream/987654321/100230/2/Territorial+disputes+in the+South+China+Sea+under+San+Francisco+Treaty.pdf

James Hoare, Susan Pares. (2005) A Political and Economic Dictionary of East Asia. Psychology Press.

Jessica Chen Weiss (2013). Authoritarian Signaling, Mass Audiences, and Nationalist Protest in China.

International Organization, 67, pp 135 doi:10.1017/S0020818312000380.(retrieved on 20 May 2015)

Jim Sciutto.Exclusive: China warns U.S. surveillance plane. By Jim Sciutto, Chief National Security

Correspondent.Updated 2342 GMT (0642 HKT) May 21, 2015.(retrieved on 20 May 2015)

Jonathan Fenby(2014) Will China Dominate the 21st Century? Polity Press

KavalskiE(2009).China and the Global Politics of Regionalization. Ashgate Publishing, Ltd. (retrieved on 20 May 2015)

Kavalski E (2012b) Central Asia and the Rise of Normative Powers: Contextualizing the Security

Governance of the EU, China, and India. New York: Continuum. (retrieved on 20 May 2015)

Kavalski E(2013). The struggle for recognition of normative powers: Normative power Europe and normative power China in context.http://cac.sagepub.com/content/48/2/247.short(retrieved on 20 May 2015)

Kavalski, E. (2014), The Shadows of Normative Power in Asia: Framing the International Agency of

China, India, and Japan. Pacific Focus, 29: 303-328. doi:

10.1111/pafo.12032http://onlinelibrary.wiley.com/doi/10.1111/pafo.12032/abstract. (retrieved on 20 May 2015)

Lee Kuan Yew (2013). The Grand Master's Insights on China, the United States, and the World (Belfer

Center Studies in International Security) Graham Allison(chapter 1 the future of China)

LeszekBuszynski. The development of the South China Sea maritime dispute.Leszek

Buszynski,Visiting Fellow, National Security College, Australian National University.http://nsc.anu.edu.au/documents/occasional-5-brief-1.pdf(retrieved on 20 May 2015)

Louie Dane C. Merced. Environmental turn in the South China 
Sea.disputes.http://www.rappler.com/world/specials/93371-cirss-commentaries-environmental-turn-south-china -sea-disputes. Published 7:15 AM, May 18, 2015.(retrieved on 20 May 2015)

Manners Ian, 'Normative Power Europe: A Contradiction in Terms?' Journal of Common Mar-ket

Studies, 2002, Vol. 40, No. 2, pp. 235-258. (retrieved on 20 March 2015)

Manners I (2009) The Concept of Normative Power in World Politics. Copenhagen: Danish Institute for International Studies Brief.

http://diggy.ruc.dk/bitstream/1800/8903/1/Ian_Manners_the_concept_of_normative_power_in_world_ politics_DIIS_Brief_2009.pdf. (retrieved on 30 March 2015)

Manners Ian (2015) Normative Power more relevant than ever. European Global (retrieved on 20

May 2015) Strategy.http://www.euglobalstrategy.eu/nyheter/opinions/manners-eu-is-still-a-normative-power.

Martin Jacques (2012) When China Rules the World: The End of the Western World and the Birth of

a New Global Order. New York: The Penguin Press.

Michael Forsythe. January 30, 2015. Roderick MacFarquhar on Xi Jinping’s High-Risk Campaign to

Save the Communist Party.

http://sinosphere.blogs.nytimes.com/2015/01/30/q-and-a-roderick-macfarquhar-on-xi-jinpings-high-ris k-campaign-to-save-the-communist-party/?_r=0(retrieved on 2 May 2015)

Ministry of Foreign Affairs of the People's Republic of China. Xi Jinping Delivers Important Speech in

Germany, Stressing China Will Unswervingly Adhere to the Path of Peaceful Development.http://www.fmprc.gov.cn/mfa_eng/topics_665678/xjpzxcxdsjhaqhfbfwhlfgdgblshlhgjkezzzbomz b_666590/t1143914.shtml(retrieved on 24 May 2015)

Paul Dibb, and John Lee (2014) Why China Will Not Become the Dominant Power in Asia.

http://www.hudson.org/research/10818-why-china-will-not-become-the-dominant-power-in-asia (retrieved on 20 May 2015)

Peter Westmore (2010). FOREIGN AFFAIRS: China's military build-up threatens

Taiwan.http://www.newsweekly.com.au/article.php?id=4510(retrieved on 20 May 2015)

Said, Edward (1977) Orientalism. London: Penguin.

http://www.odsg.org/Said_Edward(1977)_Orientalism.pdf(retrieved on 20 May 2015)

Southeast Asia Divided on Response to Chinese Reclamation in South China Sea.

http://www.wsj.com/articles/asean-chief-says-cant-accept-beijings-south-china-sea-claims-1430022922

Peter Nolan (2013) Is China buying the world? Wiley.

Pew Research Cenre. Global Attitudes and Trends.

http://www.pewglobal.org/2013/07/18/americas-global-image-remains-more-positive-than-chinas/ (retrieved on 30 April 2015)

$\mathrm{Pu}$ Xiaoyu (2012) Socialization as a two-way process: emerging powers and the diffusion of

international norms. Chinese Journal of International Politics. http://cjip.oxfordjournals.org/content/5/4/341.full (retrieved on 30 March 2015)

Roy Smith: Roy Smith http://www.bloomberg.com/news/articles/2015-03-02/china-will-be-

superpower-that-wasn-t-sage-of-japan-demis (retrieved on 30 March 2015)

Tobias Reichenbach, May 2008 A brief survey on 'Normative Power Europe'. http://www.celsius-

europe.eu/wp-content/uploads/Normative-Power-Europe.pdf

Wang Yiwei(2012), "The Identity Dilemmas of EU Normative. Shanghai Institute for European

Stdies(SIES).SIES-WP-VOL2012-№2.http://www.sies-cn.org/UploadFiles/file/WorkingPaper/20120531020813 1850_\%E3\%80\%8AWorkingPaper\%E3\%80\%8B2012\%E5\%B9\%B4\%E7\%AC\%AC02\%E6\%9C\%9F. pdf.pdf(retrieved on 20 May 2015)

When China Rules the World. We'll See....By Dan Harris on September 1st, 2011

http://www.chinalawblog.com/2011/09/when_china_rules_the_world_well_see.html (retrieved March 2015)

Youlan Feng (1983) A History of Chinese Philosophy, Volume 1. Princeton University Press.(retrieved

on 20 May 2015)

Zhang Yu (2015) Proper way needed to explain China's experience in China Social Sciences.

http://www.csstoday.com/Item/1739.aspx(retrieved on 30 March 2015) 